Published in final edited form as:

Invest New Drugs. 2012 February ; 30(1): 335-340. doi:10.1007/s10637-010-9491-6.

\title{
Phase II trial of sunitinib in patients with metastatic non-clear cell renal cell carcinoma
}

\author{
Ana M. Molina, \\ Genitourinary Oncology Service, Department of Medicine, Memorial Sloan-Kettering Cancer \\ Center, 1275 York Avenue, New York, NY 10065, USA \\ Department of Medicine, Weil Medical College of Cornell University, New York, NY, USA \\ Darren R. Feldman, \\ Genitourinary Oncology Service, Department of Medicine, Memorial Sloan-Kettering Cancer \\ Center, 1275 York Avenue, New York, NY 10065, USA \\ Department of Medicine, Weil Medical College of Cornell University, New York, NY, USA \\ Michelle S. Ginsberg, \\ Department of Medical Imaging, Memorial Sloan-Kettering Cancer Center, 1275 York Avenue, \\ New York, NY 10065, USA
}

Glenn Kroog,

Genitourinary Oncology Service, Department of Medicine, Memorial Sloan-Kettering Cancer Center, 1275 York Avenue, New York, NY 10065, USA

Department of Medicine, Weil Medical College of Cornell University, New York, NY, USA

Satish K. Tickoo,

Department of Pathology, Memorial Sloan-Kettering Cancer Center, 1275 York Avenue, New York, NY 10065, USA

\section{Xiaoyu Jia,}

Department of Biostatistics and Epidemiology, Memorial Sloan-Kettering Cancer Center, 1275

York Avenue, New York, NY 10065, USA

\section{Murielle Georges,}

Genitourinary Oncology Service, Department of Medicine, Memorial Sloan-Kettering Cancer Center, 1275 York Avenue, New York, NY 10065, USA

\section{Sujata Patil,}

Department of Biostatistics and Epidemiology, Memorial Sloan-Kettering Cancer Center, 1275

York Avenue, New York, NY 10065, USA

Michael S. Baum,

Cardiology Service, Department of Medicine, Memorial Sloan-Kettering Cancer Center, 1275

York Avenue, New York, NY 10065, USA

Victor E. Reuter, and

Department of Pathology, Memorial Sloan-Kettering Cancer Center, 1275 York Avenue, New York, NY 10065, USA

Robert J. Motzer

(C) Springer Science+Business Media, LLC 2010

Correspondence to: Robert J. Motzer, motzerr@mskcc . org. 
Genitourinary Oncology Service, Department of Medicine, Memorial Sloan-Kettering Cancer

Center, 1275 York Avenue, New York, NY 10065, USA

Department of Medicine, Weil Medical College of Cornell University, New York, NY, USA

Robert J. Motzer: motzerr@mskcc.org

\section{Summary}

Sunitinib is associated with a robust objective response rate in patients with metastatic clear cell renal cell carcinoma (RCC). The primary objective of this phase II clinical trial was to assess the overall response rate for sunitinib in patients with papillary metastatic RCC as well as other nonclear cell histologies. A Simon 2-stage design was used to determine the number of papillary metastatic RCC patients for enrollment, and allowed for descriptive response data for other nonclear cell histologies. Twenty-three patients were enrolled, including 8 with papillary renal cell carcinoma (RCC) and the remainder with other non-clear cell histologies (unclassified in 5 patients). All patients received $50 \mathrm{mg}$ of oral sunitinib in cycles of 4 weeks followed by 2 weeks of rest (4/2). The trial was stopped early because of slow accrual; no responses were observed in the 8 patients with papillary RCC. In the 22 evaluable patients, best response to sunitinib included a partial response in 1 patient with unclassified RCC, stable disease in 15, and progression in 6. The median progression-free survival was 5.5 months (95\% CI, 2.5-7.1) in all 23 patients, and 5.6 months for the 8 papillary patients $(95 \% \mathrm{CI}, 1.4-7.1)$. The robust objective responses sunitinib had produced in clear cell RCC could not be demonstrated in this study comprised of patients with non-clear cell histologies.

\section{Keywords}

Papillary renal cell carcinoma; Non-clear cell renal cell carcinoma; Sunitinib; Phase II trial

Renal cell carcinoma (RCC) is composed of several histologies including clear (conventional), papillary, chromophobe, collecting duct/medullary, and unclassified cell types [1-6]. Clear cell, the predominant cell type, comprises approximately $80 \%$ of renal epithelial tumors. The remaining renal neoplasms, collectively identified as non-clear cell RCC, consist of papillary (the most common), chromophobe, collecting duct/medullary, and unclassified cell types [2]. Recently, an improved understanding of the mechanisms involved in RCC growth and angiogenesis has prompted the development and implementation of anti-angiogenesis targeted therapies in the treatment paradigm for metastatic RCC (MRCC). Small-molecule targeted inhibitors including sunitinib have demonstrated antitumor activity in randomized phase III clinical trials [7-13], and have assumed a predominant role in standard management for metastatic clear-cell RCC.

Historically, the non-clear cell histologies are characterized by poor prognosis and resistance to systemic chemotherapy and cytokine therapy in the metastatic setting [14-17]. Data on the efficacy of targeted therapy for non-clear cell subtypes is limited to a few retrospective studies [18], and overall remains poorly defined. We sought to evaluate the efficacy of sunitinib in patients with metastatic papillary RCC as well as other less common types of non-clear cell RCC.

\section{Patient and methods}

\section{Patient eligibility}

Twenty-three patients with metastatic papillary and other non-clear cell histologies were entered into a phase II clinical trial of sunitinib at Memorial Sloan-Kettering Cancer Center (MSKCC) from March 2007 to October 2009. Eligibility criteria included histologically 
confirmed advanced RCC of papillary or other non-clear cell histology; evidence of measurable metastatic disease; Karnofsky performance status (KPS) $\geq 70 \%$; absolute neutrophil count $(\mathrm{ANC}) \geq 1,500$ cells $/ \mu \mathrm{L}$; platelet count $\geq 100,000$ cells $/ \mu \mathrm{L}$; hemoglobin $\geq 9.0 \mathrm{~g} / \mathrm{dL}$; serum calcium $\leq 12.0 \mathrm{mg} / \mathrm{dL}$; serum creatinine $\leq 1.5$ times the upper limit of normal; total serum bilirubin $\leq 1.5$ times the upper limit of normal; serum AST and ALT $\leq 2.5$ times the upper limit if liver function abnormalities were caused by underlying malignancy. Patients with tumors containing sarcomatoid features were eligible and there was no limit to the percentage of sarcomatoid involvement. Patients were excluded if they had received prior therapy with sunitinib or had major surgery or radiation therapy within 4 weeks of starting the study treatment. Before beginning treatment with sunitinib, each patient was evaluated with a history and physical examination, KPS determination, complete blood count, screening blood chemistry panel with electrolytes, thyroid panel, amylase, lipase, urinalysis, electrocardiogram, and appropriate radiographic imaging for measurable disease. A negative pregnancy test was required for women of childbearing potential. All patients gave informed consent; the trial was reviewed and approved by the Institutional Review Board at MSKCC. All pathology was reviewed and classified at MSKCC (VR and $\mathrm{ST})$.

\section{Treatment plan}

Once daily, $50 \mathrm{mg}$ of sunitinib was administered orally for 4 consecutive weeks followed by a 2 -week break ( $4 / 2$ schedule), comprising a complete cycle of 6 weeks.

\section{Toxicity and response criteria}

All toxicities were evaluated based on the National Cancer Institute Common Toxicity Criteria for Adverse Events (CTCAE, v3.0). Dose reductions were performed depending on the type and severity of toxicity encountered, as previously described [7]. Grade 4 neutropenia, grade $\geq 3$ thrombocytopenia, grade $\geq 3$ fatigue, and grade 4 hand-foot syndrome resulted in a reduction of 1 dose level. In addition, patients were instructed to withhold sunitinib for grade 3 hand-foot syndrome and any other nonhematologic grade 3 or 4 toxicity until the toxicity reached grade $\leq 1$, with reinstitution at either the same dose level or 1 dose level reduction at the discretion of the investigator.

Interim assessment of tumor status was performed by radiographic imaging at baseline, every 6 weeks for cycles $2-4$, then on even-numbered cycles (ie, 6, 8). Responses were evaluated according to the Response Evaluation Criteria in Solid Tumors (RECIST). Treatment was continued until disease progression ( $\geq 20 \%$ increase in tumor size), unacceptable toxicity, or patient withdrawal.

\section{Statistics}

The sample size and stopping rules were determined according to a Simon 2-stage design, in which a response rate of $\geq 20 \%$ was considered promising and a response rate of $\leq 5 \%$ was unacceptable [19]. With a type I error of 5\% and a type II error of 20\%, 12 papillary RCC patients would initially be enrolled and treated with sunitinib, with planned enrollment expanded to 37 patients with papillary RCC if at least 1 patient responded. The trial allowed for descriptive response data for other rare non-clear cell histologies. Slow accrual of patients with papillary histology caused early closure of the study.

\section{Results}

\section{Patient characteristics}

Twenty three patients began treatment with sunitinib (Table 1). The median age of study patients was 55; 18 (78\%) patients had undergone prior nephrectomy. There was a relatively 
high proportion of patients with lung (43\%) and lymph node (83\%) metastases. Sixteen patients (70\%) had $\geq 2$ metastatic sites. Three patients had received prior therapy: 1 had prior cytokine and targeted therapy (temsirolimus), 1 had targeted therapy (temsirolimus), and 1 received chemotherapy. Non-clear cell histologies included 8 (35\%) papillary, 2 (9\%) chromophobe, 4 (17\%) collecting duct, 1 (4\%) medullary, 5 (22\%) unclassified and $3(13 \%)$ had hereditary leiomyomatosis and renal cell cancer-related RCC (HLRCC). Genetic testing for HLRCC was performed on 1 out of 3 HLRCC-related tumors. One of the patients with unclassified histology had a possible translocation-associated RCC. Sarcomatoid features were present in 3 ( 2 collecting duct and 1 unclassified) out of the 23 patients.

Papillary RCC patients and other rare non-clear cell histology patients were analyzed separately. Descriptive statistics were provided on patient characteristics, toxicities, and responses. Kaplan-Meier method [20] was used to estimate progression free survival (PFS)

\section{Response}

One patient discontinued protocol treatment due to toxicity prior to completion of cycle 1 , leaving 22 patients evaluable for response (Table 1). One patient with unclassified RCC achieved a partial response to sunitinib treatment. The patient progressed after 36 weeks of therapy. Fifteen (65\%) had a best response of stable disease (SD). One patient with SD remains on therapy after 48 weeks. The remaining 14 patients with SD developed progressive disease on treatment. Six $(26 \%)$ patients were noted to have progressive disease at their first reassessment. For each of the 22 evaluable patients, the maximum reduction in tumor size during treatment and RCC histology are displayed in Fig. 1. PFS was assessed in all 23 patients from start of sunitinib therapy (Fig. 2). The median PFS was 5.5 months (95\% CI, 2.5-7.1). Similarly, the median PFS for the 8 papillary patients was 5.6 months (95\% CI, 1.4-7.1).

\section{Toxicity}

All twenty three (100\%) patients were evaluable for toxicity. In general, the treatment was well tolerated. The most common toxicities are listed in Table 2; the safety profile was compatible with prior reports [13].

\section{Discussion}

The primary objective of this phase II clinical trial was to assess the overall response rate for sunitinib in patients with papillary mRCC as well as other non-clear cell histologies. Only 1 partial response was observed in a patient with unclassified $\mathrm{mRCC}$, and no objective responses were observed in patients with papillary $\mathrm{mRCC}$. The robust activity of sunitinib in producing objective responses in patients with clear cell RCC $[7,13,21]$ was lacking in this study comprised of patients with non-clear cell histologies.

Our findings are consistent with recent reports citing few responses to treatment with sunitinib in subsets of patients with non-clear cell histologies [22, 23]. One phase II study of sunitinib therapy in non-clear cell histologies recently reported no major responses, a median PFS of 1.6 months (95\% CI, 1.3-12), and OS of 10.8 months (95\% CI, 6.2-NE) in a subset of papillary patients [24]. More encouraging results in patients with non-clear cell histologies have been observed with agents targeting pathways other than VEGF. For example, in a large phase 3 trial, the mammalian target of rapamycin (mTOR) inhibitor, temsirolimus, demonstrated a significant survival benefit over interferon in patients with metastatic RCC of any histology. In fact, in a subset analysis, the benefit appeared to be more significant in patients with non-clear-cell histology [5]. Similarly, an 11\% objective response rate was achieved in a recent study assessing the epidermal growth factor receptor 
(EGFR) inhibitor, erlotinib, in 45 patients with papillary RCC [25]. These agents may therefore hold more promise (both alone or as part of combination regimens) than the VEGF pathway inhibitors for patients with non-clear cell RCC.

In summary, non-clear cell histologies represent an uncommon and heterogeneous group of RCC for which effective treatments have not yet been found. The study of novel agents and identification of specific targets in these RCC groups is a direction for the future.
Abbreviations
mRCC
Metastatic renal cell carcinoma
RCC
Renal cell carcinoma
HLRCC
Hereditary leiomyomatosis and renal cell cancer
CTCAE
Common toxicity criteria for adverse events
RECIST
Response evaluation criteria in solid tumors

\section{Acknowledgments}

This study was supported in part by Pfizer, Inc. The authors wish to thank Carol Pearce, MSKCC Department of Medicine writer/editor, for her review of this manuscript.

\section{References}

1. Motzer RJ, Bander NH, Nanus DM. Renal-cell carcinoma. N Engl J Med. 1996; 335:865-875. [PubMed: 8778606]

2. Reuter VE, Presti JC Jr. Contemporary approach to the classification of renal epithelial tumors. Semin Oncol. 2000; 27:124-137. [PubMed: 10768592]

3. van den Berg E, van der Hout AH, Oosterhuis JW, Storkel S, Dijkhuizen T, Dam A, Zweers HM, Mensink HJ, Buys CH, de Jong B. Cytogenetic analysis of epithelial renal-cell tumors: relationship with a new histopathological classification. Int J Cancer. 1993; 55:223-227. [PubMed: 8370620]

4. Weiss LM, Gelb AB, Medeiros LJ. Adult renal epithelial neoplasms. Am J Clin Pathol. 1995; 103:624-635. [PubMed: 7741111]

5. Kovacs G, Szucs S, De Riese W, Baumgartel H. Specific chromosome aberration in human renal cell carcinoma. Int J Cancer. 1987; 40:171-178. [PubMed: 3610386]

6. Fleming S. The impact of genetics on the classification of renal carcinoma. Histopathology. 1993; 22:89-92. [PubMed: 8436349]

7. Motzer RJ, Hutson TE, Tomczak P, Michaelson MD, Bukowski RM, Rixe O, Oudard S, Negrier S, Szczylik C, Kim ST, Chen I, Bycott PW, Baum CM, Figlin RA. Sunitinib versus interferon alfa in metastatic renal-cell carcinoma. N Engl J Med. 2007; 356:115-124. [PubMed: 17215529]

8. Hudes G, Carducci M, Tomczak P, Dutcher J, Figlin R, Kapoor A, Staroslawska E, Sosman J, McDermott D, Bodrogi I, Kovacevic Z, Lesovoy V, Schmidt-Wolf IG, Barbarash O, Gokmen E, O'Toole T, Lustgarten S, Moore L, Motzer RJ. Temsirolimus, interferon alfa, or both for advanced renal-cell carcinoma. N Engl J Med. 2007; 356:2271-2281. [PubMed: 17538086]

9. Motzer RJ, Escudier B, Oudard S, Hutson TE, Porta C, Bracarda S, Grunwald V, Thompson JA, Figlin RA, Hollaender N, Urbanowitz G, Berg WJ, Kay A, Lebwohl D, Ravaud A. Efficacy of everolimus in advanced renal cell carcinoma: a double-blind, randomised, placebo-controlled phase III trial. Lancet. 2008; 372:449-456. [PubMed: 18653228]

10. Escudier B, Eisen T, Stadler WM, Szczylik C, Oudard S, Siebels M, Negrier S, Chevreau C, Solska E, Desai AA, Rolland F, Demkow T, Hutson TE, Gore M, Freeman S, Schwartz B, Shan M, Simantov R, Bukowski RM. Sorafenib in advanced clear-cell renal-cell carcinoma. N Engl J Med. 2007; 356:125-134. [PubMed: 17215530] 
11. Escudier B, Koralewski P, Pluzanska A, Ravaud A, Bracarda S, Szczylik C, Chevreau C, Filipek M, Melichar B, Moore N. on behalf of the Ai. A randomized, controlled, double-blind phase III study (AVOREN) of bevacizumab/interferon- $\{$ alpha $\} 2$ a vs placebo/interferon- $\{$ alpha $\} 2 \mathrm{a}$ as firstline therapy in metastatic renal cell carcinoma. J Clin Oncol (Meeting Abstracts). 2007; 25:3.

12. Rini BI, Halabi S, Rosenberg JE, Stadler WM, Vaena DA, Ou SS, Archer L, Atkins JN, Picus J, Czaykowski P, Dutcher J, Small EJ. Bevacizumab plus interferon alfa compared with interferon alfa monotherapy in patients with metastatic renal cell carcinoma: CALGB 90206. J Clin Oncol. 2008; 26:5422-5428. [PubMed: 18936475]

13. Motzer RJ, Hutson TE, Tomczak P, Michaelson MD, Bukowski RM, Oudard S, Negrier S, Szczylik C, Pili R, Bjarnason GA, Garcia-del-Muro X, Sosman JA, Solska E, Wilding G, Thompson JA, Kim ST, Chen I, Huang X, Figlin RA. Overall survival and updated results for sunitinib compared with interferon alfa in patients with metastatic renal cell carcinoma. J Clin Oncol. 2009; 27:3584-3590. [PubMed: 19487381]

14. Mai KT, Landry DC, Robertson SJ, Commons AS, Burns BF, Thijssen A, Collins J. A comparative study of metastatic renal cell carcinoma with correlation to subtype and primary tumor. Pathol Res Pract. 2001; 197:671-675. [PubMed: 11700888]

15. Motzer RJ, Bacik J, Mariani T, Russo P, Mazumdar M, Reuter V. Treatment outcome and survival associated with metastatic renal cell carcinoma of non-clear-cell histology. J Clin Oncol. 2002; 20:2376-2381. [PubMed: 11981011]

16. Upton MP, Parker RA, Youmans A, McDermott DF, Atkins MB. Histologic predictors of renal cell carcinoma response to interleukin-2-based therapy. J Immunother. 2005; 28:488-495. [PubMed: 16113605]

17. Motzer RJ, Russo P. Systemic therapy for renal cell carcinoma. J Urol. 2000; 163:408-417. [PubMed: 10647643]

18. Choueiri TK, Plantade A, Elson P, Negrier S, Ravaud A, Oudard S, Zhou M, Rini BI, Bukowski RM, Escudier B. Efficacy of sunitinib and sorafenib in metastatic papillary and chromophobe renal cell carcinoma. J Clin Oncol. 2008; 26:127-131. [PubMed: 18165647]

19. Simon R. Optimal two-stage designs for phase II clinical trials. Control Clin Trials. 1989; 10:1-10. [PubMed: 2702835]

20. Kaplan EL, Meier P. Nonparametric estimation from incomplete observations. J Am Stat Assoc. 1958; 53:457-481.

21. Motzer RJ, Rini BI, Bukowski RM, Curti BD, George DJ, Hudes GR, Redman BG, Margolin KA, Merchan JR, Wilding G, Ginsberg MS, Bacik J, Kim ST, Baum CM, Michaelson MD. Sunitinib in patients with metastatic renal cell carcinoma. JAMA. 2006; 295:2516-2524. [PubMed: 16757724]

22. Ravaud A, Oudard S, Gravis-Mescam G, Sevin E, Zanetta S, Theodore C, de Fromont M, MahierAit Oukhatar C, Chene G, Escudier B. First-line sunitinib in type I and II papillary renal cell carcinoma (PRCC): SUPAP, a phase II study of the French Genito-Urinary Group (GETUG) and the Group of Early Phase trials (GEP). J Clin Oncol (Meeting Abstracts). 2009; 27:5146.

23. Plimack ER, Jonasch E, Bekele BN, Smith LA, Araujo JC, Tannir NM. Sunitinib in non-clear cell renal cell carcinoma (ncc-RCC): a phase II study. J Clin Oncol (Meeting Abstracts). 2008; 26:5112.

24. Plimack ER, Jonasch E, Bekele BN, Qiao W, Ng CS, Tannir NM. Sunitinib in papillary renal cell carcinoma (pRCC): results from a single-arm phase II study. J Clin Oncol (Meeting Abstracts). 2010; $28: 4604$.

25. Gordon MS, Hussey M, Nagle RB, Lara PN Jr, Mack PC, Dutcher J, Samlowski W, Clark JI, Quinn DI, Pan CX, Crawford D. Phase II study of erlotinib in patients with locally advanced or metastatic papillary histology renal cell cancer: SWOG S0317. J Clin Oncol. 2009; 27:5788-5793. [PubMed: 19884559] 


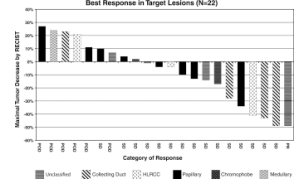

Fig. 1.

Maximal percentage of tumor reduction for target lesions by Response Evaluation Criteria in Solid Tumors (RECIST) 


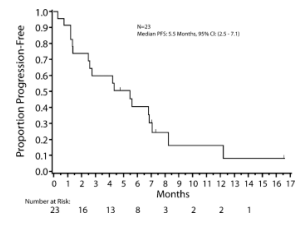

Fig. 2.

Progression-free survival $(N=23)$ 
Table 1

Patient characteristics and best responses to sunitinib treatment $(N=23)$

\begin{tabular}{|c|c|c|c|c|}
\hline \multirow[t]{2}{*}{ Characteristic } & \multirow[t]{2}{*}{ Papillary $(N=8)$} & \multirow[t]{2}{*}{ Other non-clear cell $(N=15)$} & \multicolumn{2}{|l|}{ All patients } \\
\hline & & & $(N=\mathbf{2 3})$ & $\%$ \\
\hline \multicolumn{5}{|l|}{ Sex } \\
\hline Male & 7 & 10 & 17 & 74 \\
\hline Female & 1 & 5 & 6 & 26 \\
\hline \multicolumn{5}{|l|}{ Age, y } \\
\hline Median (range) & $69(35$ to 80$)$ & $53(21$ to 72$)$ & 55 (21 to 80$)$ & \\
\hline \multicolumn{5}{|l|}{ Race } \\
\hline White non-Hispanic & 6 & 12 & 18 & 78 \\
\hline Black non-Hispanic & 1 & 2 & 3 & 13 \\
\hline Other & 1 & 1 & 2 & 9 \\
\hline Prior nephrectomy & 6 & 12 & 18 & 78 \\
\hline \multicolumn{5}{|l|}{ Prior systemic treatment } \\
\hline Interferon-alfa & 1 & 0 & 1 & 4 \\
\hline Temsirolimus & 1 & 1 & 2 & 9 \\
\hline Cisplatin/gemcitabine & 0 & 1 & 1 & 4 \\
\hline \multicolumn{5}{|l|}{ Histology subtype } \\
\hline Papillary & 8 & - & 8 & 35 \\
\hline Chromophobe & - & 2 & 2 & 9 \\
\hline Collecting duct & - & 4 & 4 & 17 \\
\hline Medullary & - & 1 & 1 & 4 \\
\hline Unclassified & - & 5 & 5 & 22 \\
\hline HLRCC-related & - & 3 & 3 & 13 \\
\hline \multicolumn{5}{|l|}{ Sites of metastatic disease } \\
\hline Lung & 5 & 5 & 10 & 43 \\
\hline Liver & 0 & 2 & 2 & 9 \\
\hline Bone & 0 & 1 & 1 & 4 \\
\hline Lymph nodes & 7 & 12 & 19 & 83 \\
\hline Other & 2 & 9 & 11 & 48 \\
\hline
\end{tabular}

No. of metastatic sites

$\begin{array}{lrrrr}1 & 3 & 4 & 7 & 30 \\ \geq 2 & 5 & 11 & 16 & 70\end{array}$

Karnofsky performance status (\%)

80

90

MSKCC risk group [14]

Favorable

Intermediate

Poor

Best response to sunitinib

\section{1}

7

3
5
0

$\begin{array}{rrr}4 & 5 & 22 \\ 11 & 18 & 78\end{array}$




\begin{tabular}{|c|c|c|c|c|}
\hline \multirow{2}{*}{ Characteristic } & \multirow[t]{2}{*}{ Papillary $(N=8)$} & \multirow[t]{2}{*}{ Other non-clear cell $(N=15)$} & \multicolumn{2}{|l|}{ All patients } \\
\hline & & & $(N=\mathbf{2 3})$ & $\%$ \\
\hline Partial response & 0 & 1 & 1 & 4 \\
\hline Stable disease & 6 & 9 & 15 & 65 \\
\hline Progressive disease & 2 & 4 & 6 & 26 \\
\hline Not evaluable & 0 & 1 & 1 & 4 \\
\hline
\end{tabular}




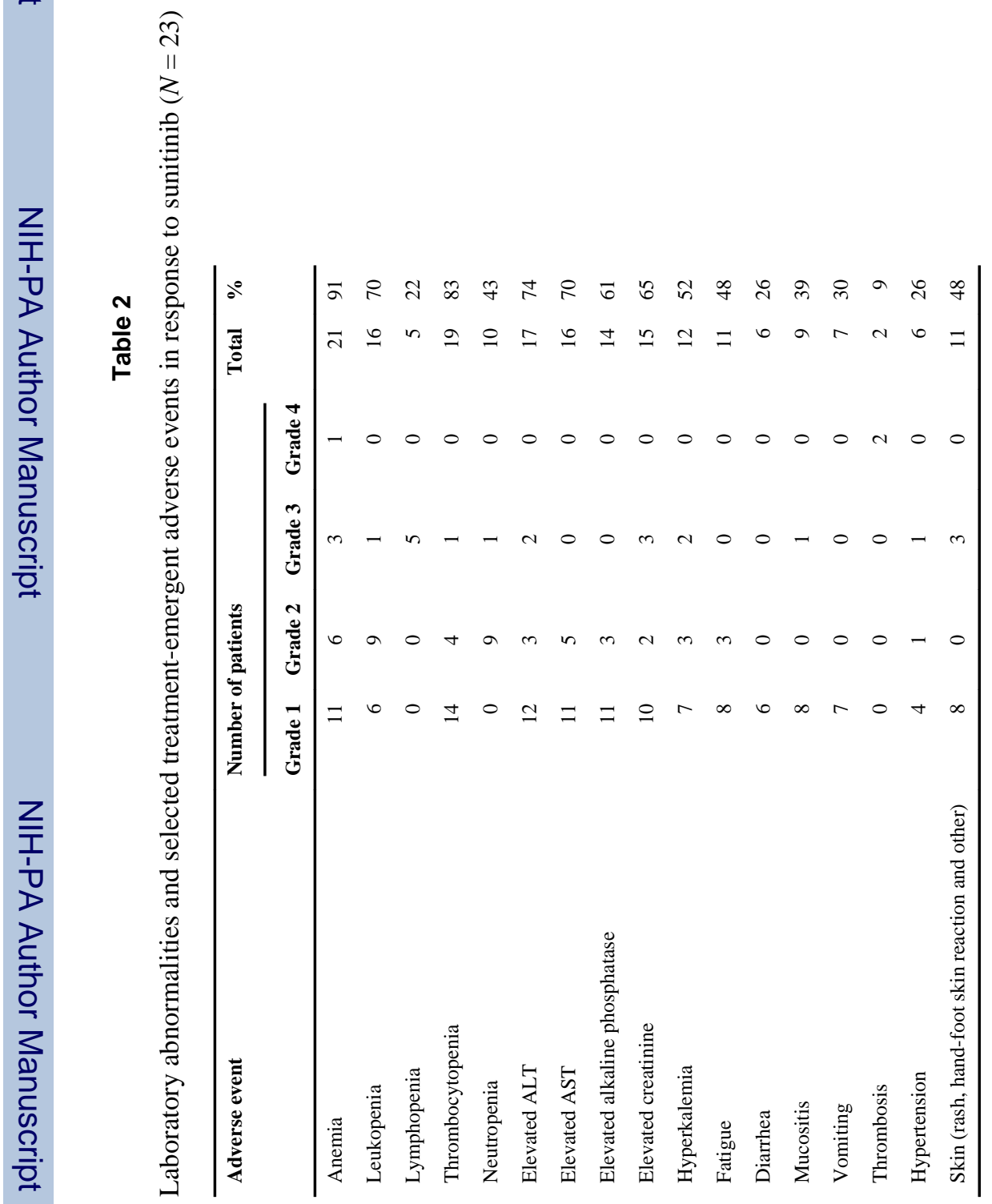

